ated clouds float into the wind in opposition to all known physical laws?

I cannot help but think that had a meteorologist been on the spot, he would have been able to throw light on the subject of cloud formation and precipitation. Aluvah A. Eaton. Riverdale, C\&l., May 20.

\section{Birds that Sing in the Night.}

I waS somewhat surprised that the writers under the above caption in the Dec. 2 and 16 Nos. of Science omitted some of the most familiar night-singers of the Atlantic seaboard of the latitude of New England. While never having heard some of those mentioned, I have often heard the field-sparrow, Shizella pusilla, break forth into rapturous song by night, especially if the moon be shining, at the nesting period.

Another of the most common night-singers is that songster of songsters, the prince of the thrushes, the Wilson's thrush, or "Marten," Turdus fuscescens. During late May, June, and early July he prolongs his vespers till nine or ten o'clock, and of ten breaks forth at intervals throughout the rest of the night.

Another songster is the cuckoo, whether the yellow or bluebilled, I know not. He generally sings in the low ground, and is popularly supposed to foretell rain. "Oft in the stilly night," while the moon was playing hide and seek with the clouds, and a thin mist was creeping slowly over the landscape, have I heard the "rain-bird's" voice come weirdly from the swamps. At first low and indistinct, perhaps owing to the inequalities of the atmosphere, a few steps may suffice to place one so it is heard with startling distinctness. At such times the sweetness of his voice is enhanced, and, as the clear, liquid notes swell on the stillness, we forget to quote Shakespeare: "The nightengale if she should sing by day, would be thought no better a musician than the wren," but rather burst into the rapturous quotation of a later poet:-

$$
\begin{aligned}
& \text { "O cuckoo! shall I call the bird } \\
& \text { Or but a wandering voice!" }
\end{aligned}
$$

Then we forget the songster's ill-repute as an egg-thief, forget his benefits to the agriculturist, and love to feel the author of this melody is of supramundane origin, and not of earth, earthy. If a few birds' eggs mixed with a diet of tent caterpillars will make such a voice, let him have them, by all means. I heartily believe the bluejay is author of most of the mischief laid to his door, as I have seen him take both eggs and young of the smaller birds.

The horned lark, Otocoris a rubea, is the most common nightsinger in California, at least the valley. ALvaH A. Eaton. Riverdale, Callfornia.

\section{Books for Children.}

Mr. Frank WaLdo, in Science for June 16, asks for lists of books that will enable children of ten to call by name the natural objects they meet in their rambles.

He says that those books which he has seen do not give the "necessary details." Therein lies the difficulty with children of ten years of age. As soon as the necessary details are given so many scientific words have of necessity been used that the results are beyond the comprehension of the clientage to which he proposes to cater. Those whom he wishes to reach, need just what he himself states at the end of his letter he was so fortunate as to have, viz, a personal guide and instructor.

The best book. for children, about flowers, with which I am acquainted, is Gray's, "How Plants Grow." Bright children of 12, if properly instructed, could use it in the woods and fields and find out, without the presence of a teacher at the time, the name of any of the larger and more interesting of the flowers, excluding, of course, the golden rods, daisies and other compositæ.

In the correspondent's state, New Jersey, there are several hundred species of birds, and many of them have nests and eggs so nearly alike, that by them even oölogists cannot tell the species with certainty. Most birds give several different notes, some an extensive range; nearly all sing differently at different times of the year. The bird book asked for - one that will enable a person of ten or any other age to name "free birds" without a teacher - is an impossibility.

The best book on birds, is probably Coues's "Key to North American Birds," but it could not be used by children under 15.

French's "Butterflies of the Eastern United States," is probably rudimentary enough for children of $12-14$, provided a little preliminary work were done by an older person who understands the vocabulary used by the author. My own "Trees of the Northern United States" deals only with the leaves, bark, and occasionally the fruit, and contains as few scientific words as possible, and those are all defined with added illustrations whenever at all necessary. This fact, and its containing an accurate picture of the leaf of each species, ought to enable even those of ten to use the book. Binney's "Land and Fresh Water Shells of North America" contains illustrations of all the species, and, as far as these will enable one to name shells, ought to be all right for children. I attempted in my "Mollusks of the Atlantic Coast" to make an easy book to be used by children of 14 or more in naming the shells of the shore.

The beetles are too numerous in species for any book, large or small, expensive or otherwise, to enable children or even grown people to name all or even a majority of them. The moths are also very numerous in species and so far no one book, cheap or high priced, names them all. Austin C. Apgar.

Trenton, N. J.

\section{Teaching of Biology.}

THE recent discussion in the pages of Science as to the methods of teaching biology now in vogue in this country, has brought out much that is of interest to all who seek to present that subject in a fair and unbiased manner to their students. Ignoring the controversial phase, which too many of the letters have shown, is there not, after all, the question yet remaining-How shall biology be taught?

Circumstances are alike at no two colleges in this country; differences of courses, students, surroundings and many other factors make it necessary that each teacher should solve the problem for himself. But in a large number of institutions the plan of study is such that unless a student elects to specialize in biological lines he will receire but one, or at most two, terms of training in natural history.

In such a case what is the best plan to adopt? A course in botany will give the student a slight acquaintance with some of the flowering plants only if the course be the one usually given in such cases. On the other hand, a course in zoölogy would leave the student with no knowledge of plants and but little of animals. He will receive no farther work in either line during his course. What will be the best for him in his life after leaving college?

After much consideration, the writer bas sought to find a way between the two horns of the above dilemma by seeking to present fundamental principles, illustrating and demonstrating them by examples taken from either the animal or vegetable kingdom, as might be most adrantageous. In this work the form itself has received far less stress than the principle which it illustrated, and the bearing it might have on the question whether the course was more botanical than zoölogical was not for a moment considered.

It was found convenient to begin by assuming that, in a degree, animals and plants are machines for the transformation and utilization of energy; adding to this, during the course, a consideration of the problems which must be successfully met to ensure existence and comparative study of the various ways in which these problems are solved.

The result of this course has been to encourage me to continue along these lines, reserving for psychology, which follows, the task of checking any tendency to regard living things as machines only. Looking over the ground covered, I find that nearly two-thirds of the examples chosen to illustrate the various principles were from the vegetable kingdom. Surely, whatever else it may be, this is not a course in zoölogy masquerading under 
the guise of one in biology. Whether it agrees with the original meaning of the word "biology" or not, I care but little, for many other words of our language are very far to-day from their original significance, while a study of the principles shown by "matter in its living state," is certainly not very far from the significance of the words from which "biology" is derived.

State College, Pa., June 9. H. T. Fernald,

\section{BOOK-REVIEWS}

Fifteenth Annual Report of the State Board of Health of the State of Connecticut, for the Seven Months Ending June 30, 1892. New Haven, 1893.

In addition to the customary features, the statistics upon the health of towns and the reports of local boards of health, this volume contains three papers under the heading "Miscellaneous." The first of these is by Dr. Herbert E. Smith, upon "Connecticut River Water as a Source of Typhoid Fever at Hartford." The unusual number of cases of typhoid fever in Hartford in the winter of 1891-92 led to an investigation by Dr. Smith, under the auspices of the State Board of Health. Dr. Smith has fixed the responsibility for the outbreak upon the water of the Connecticut River, which was supplied to citizens of Hartford. during a large part of the months of October, November, and December. The period when the disease specially prevailed "corresponds with the time when cases originating in the use of the river-water must have appeared." From the evidence adduced by Dr. Smith there seems every reason to believe that typhoid germs, carried to the consumer by the river-water, were the cause of some fifteen deaths that otherwise might not have occurred. Dr. Smith suggests that the germs might have come from the sewers of Springfield, twenty-five miles up stream, and this seems certainly a likely supposition, if we are to judge from the history of similar epidemics.
The paper which follows this is by Dr. Charles J. Foote, upon "The Filtration of Water." It relates some experiments upon the Pasteur-Chamberlain filter, certain of which seem to indicate that defective packing around the porcelain may lead to the appearance of germs in the filtrate. As a result, partly of his own, partly of others' investigations, Dr. Foote concludes with the following practical advice: "We may conclude then, first, that the porcelain cylinder of a Pasteur filter should be cleansed once a week at least by boiling in water for an hour. A simple washing is not sufficient, since, when the porcelain is replaced, the living bacteria still remain in its pores and come through into the filtrate as soon as the water is turned on; second, that the filter should not be put in a position where it is near a range or any other apparatus giving out much heat, but put in a cold place; third, that a properly-constructed filter should be obtained, so that there is no chance of a leak around the packing."

The third paper is entitled, "Abstracts from a paper on the Duty of Public Disinfection following Acute Infectious Diseases," and is a remarkable production, as the following pregnant sentences may suggest: "One afternoon last December I sat upon the deck of the revenue cutter, 'Lot Morrill,' with the secretary of our State Board of Health." . . . "Smallpox has been lashed to hell by the agent raccination, and like a whimpering hound is held securely in leash." . . . "Arms, arts, literature, science, all have their rewards, but not one of them surpasses in the magnificence of its gifts those of which the god-like science, medicine, is capable."

The Archcean Formation of the Abukuma Plateau. Ву В. Кото. Journal of the College of Science, Imperial University, Japan. Vol. V., 1893. Plates.

THIs article of nearly one hundred pages and six well-executed plates shows us that Japan is not behind the western countries in scientific studies. Except a few cabalistic signs on the cover, and a few more on one page at the end of the article and a foot-note
Reading Matter Notices.

Ripans Tabules : for torpid liver. Ripans Tabules banish pain.

ACK NUMBERS and complete sets of leading Magazines. Rates low. AM. MAG. EXCHANGE.

\section{RESTORE YOUR EYESIGHT}

Cataracts, scars or films can be absorbed and pataracts, scars or films can be absorbed and paralyzed nerves restored, wisk. Diseased eyes or lids can be cured by our home treatment. "We prove it." Hnn'Home Treatment for Eyes," free. Don't miss it.
Everybody wants it. "THE EYE,"Glens Falls, N.Y.

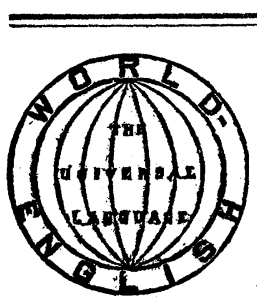

WORLD-ENGLISH. 25 Cents. WORLD-ENGLISH. 25 cents. Ex - President Andrew D.
White, of Cornell University, says: "I believe thatthe highest interests of Christian civilization and of humanity would be served by its adoption."

"So set down, our tongue is the best for the world to unite upon."-Brooklyn Eagle.

"The idea of Mr. Bell has much to recommend it, and the presentation is charmingly clear."-Ameri. can, Phila.

"The result is a language which cannot fail to meet with acceptance."-Boston Traveller.

"World. English deserves the careful consideration of all serious scholars."-Modern Language Notes.

Sent, postpaid, on receipt of price.

N. D. C. HODGES, 874 Broadway, New York. N. D. C. HODGES, 874 Broadway, New York.
THE MODERN MALADY ; or, SUfferers from 'Nerves.'

An introduction to public consideration, from a non-medical point of view, of a condition of ill-health which is increasingly prevalent in all ranks of society. In the first part of this work the author dwells on the errors in our mode of treating Neuras thenia, consequent on the wide ignorance of the subject which still prevails; in the second part, attention is drawn to the principal causes of the malady. The allegory forming the Introduction to Part I. gives a brief his tory of nervous exhaustion and the modes of treatment which have at various times been thought suitable to this most painful and trying disease.

By CYRIL BENNETT. $12^{\circ}, 184$ pp., $\$ 1.50$.

N. D. C. HODGES, 874 Broadway, N. Y. THE RADIOMETER.

BY DANIEL S. TROY.

This contains a discussion of the reasons for their action and of the phenomena presented in Crookes' tubes.

Price, postpaid, 50 cents.
Pennsylvania Bedford Springss Mineral Water For Liver, Kidney and Bladder Troubles. For Gravel, Gall Stones, Jaundice. For Dyspepsia, Rheumatism and Gout. For Hemorrhoids, Ete.

It has been used medicinally and prescribed by physicians for nearly one hundred years. DIRECTIONS:-Take one or two glasses about a half-hour before each meal.

Case One Dozen Half-Gallon Bottles, $\$ 4.50$

(Aerated), $\$ r^{\prime} .50$.

Bedford Mineral Springs Co., Bedford, Pa. Philadelphia Office, 1004 Walnut St.

\section{ESTERBROOK'S} STEEL PENS.

OF SUPERIOR AND SIANDARD QUALITY.

Leading Nos.: 048, 14, 130, 135, 239, 333

For Sale by all Stationers.

THE ESTERBROOK STEEL PEN CO.

Works: Oamden, N.J. 26 John St., NewYork.

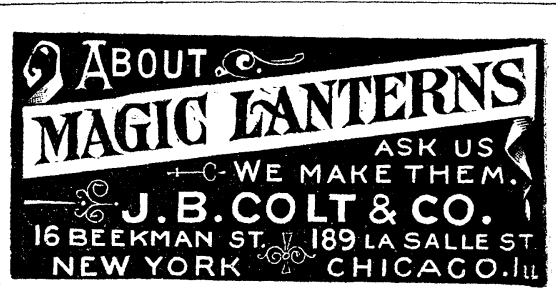

MINERALS , New store.

New Departments.

Send for our "Winter Bulletin," recently issued. Minerals, Gems, Microscopical Sections, Fine Lap. idary Work.

GEO. L. ENGLISH \& CO., Mineralogists,

Removed to 64. East 12th Street, New York 